\title{
Periodic sulfide irruptions impact microbial community structure and diversity in the water column of a hypersaline lake
}

\author{
Brandon K. Swan ${ }^{1,4}$, Kristen M. Reifel ${ }^{2}$, David L. Valentine ${ }^{3, *}$ \\ ${ }^{1}$ Marine Science Program and Department of Earth Science, University of California, 1006 Webb Hall, \\ Santa Barbara, California 93106, USA \\ ${ }^{2}$ Graduate Program in Marine Environmental Biology, Department of Biology, University of Southern California, \\ 3616 Trousdale Parkway, Los Angeles, California 90089, USA \\ ${ }^{3}$ Department of Earth Science and Marine Science Institute, University of California, 1006 Webb Hall, \\ Santa Barbara, California 93106, USA \\ ${ }^{4}$ Present address: Bigelow Laboratory for Ocean Sciences, 180 McKown Point Road, PO Box 475, \\ West Boothbay Harbor, Maine 04575, USA
}

\begin{abstract}
The occurrence of hypoxia/anoxia and sulfide formation in productive lakes, enclosed seas, and the coastal ocean often results in catastrophic loss of plankton, benthic invertebrates, and fish populations. Sulfide formed in deeper waters is mixed upward due to storm events or currents, thereby removing oxygen from large portions of the water column. Although the deleterious effects of these events on many organisms are known, the effects on microbial communities have received less attention. Archaeal and bacterial community structure and diversity were investigated at 6 stations along 2 intersecting transects passing through a sulfide-rich plume formed in the moderately hypersaline Salton Sea, California, USA. Community structure analysis clearly distinguished samples within and outside the sulfide plume, and multivariate analyses found these patterns to be correlated with sulfide concentration. Cloning and sequencing of 16S rRNA genes revealed that Actinobacteria, Gammaproteobacteria (purple sulfur bacteria), and Chlorobi (green sulfur bacteria) were more prevalent at stations with higher sulfide concentration, and Synechococcus spp. was the most abundant bacterial lineage at most stations. Archaeal diversity was low, and sequences were affiliated with Methanohalophilus spp., Methanococcoides spp., Methanosarcinales spp., many of which are related to known methylotrophs, and Marine Benthic Group (MBG)-D sequences. Compositional differences detected between stations may reflect differential tolerances or utilization of sulfide and other reduced-sulfur compounds by the planktonic microbial community.
\end{abstract}

KEY WORDS: Microbial diversity · Sulfide oxidation · Methylotrophy · Dimethylsulfide · Dimethylsulfoniopropionate $\cdot$ Gypsum precipitation · Water column anoxia $\cdot$ Hypersaline lake

\section{INTRODUCTION}

The formation of hypoxia/anoxia and accumulation of sulfide in bottom waters due to eutrophication, shifts in climatic forcing, or both has been documented in freshwater (Effler et al. 1988) and saline lakes (Watts et al. 2001, Barić et al. 2003), and the coastal ocean (Seliger et al. 1985, Turner \& Rabalais 1994, Malakoff
1998, Naqvi et al. 2000, Weeks et al. 2004, Lavik et al. 2009). In some instances, toxic levels of sulfide mix into shallower waters via storm events and changes in currents, leading to increased mortality of organisms due to long-term deoxygenation of the water column (Weeks et al. 2002, Luther et al. 2004, Ciglenečki et al. 2005, Tiffany et al. 2007a). In addition, the formation of precipitated minerals (i.e. gypsum), elemental sulfur, 
or polysulfides allow for visualization of these events from the surface (Takeda et al. 1991, Fallesen et al. 2000) and from satellite observation (Weeks et al. 2004, Tiffany et al. 2007c, Lavik et al. 2009). While affected coastal ocean regions may be larger in extent, enclosed environments such as bays, fjords, and lakes are easier to sample and monitor, and make excellent candidates for studying the effects of water quality deterioration on food webs.

The Salton Sea is a large $\left(980 \mathrm{~km}^{2}\right)$, shallow $(8 \mathrm{~m}$ average depth), eutrophic, moderately hypersaline (48 to $50 \mathrm{~g} \mathrm{l}^{-1}$ ) lake located in the southern California desert, USA (see Fig. 1). During a reconnaissance study from 1997 to 1999, the seasonal formation of anoxia and sulfide in bottom waters after thermal stratification developed was documented (Watts et al. 2001). Periodic wind storms mix oxygen-depleted, sulfide-rich bottom waters to the surface, causing mass mortality of plankton (Tiffany et al. 2002, 2007a,b), benthic invertebrates (Detwiler et al. 2002), and fish (Riedel et al. 2002), as well as the precipitation of gypsum (Tiffany et al. 2007c). Previously referred to as 'green tides' (Watts et al. 2001) and 'greening events' (Swan et al. 2007), sulfide irruption events in the Salton Sea mainly occur in late summer to early fall and can be detected and tracked remotely using satellite imagery (Tiffany et al. 2007c). Although the affects of sulfide irruptions on the macroecology of the Salton Sea have been documented, investigations of changes within the microbial community have not been conducted. Studies of potential effects on microbial diversity and community structure in other environments are also lacking (but see Lavik et al. 2009), and no studies to date have considered the archaeal component.

We sampled a sulfide irruption event on 3 September 2005 in the Salton Sea that was initially detected by satellite. Changes in bacterial and archaeal community structure and diversity as a function of water column environmental gradients (i.e. sulfide concentration) were investigated. We postulated that differences in the types and abundances of microbial taxa would reveal a 'microbial signal' within recently up-welled, sulfide-rich bottom waters, thus further distinguishing more recently mixed water masses from less affected regions. The ecological consequences and cycling of reduced sulfur compounds (i.e. dimethylsulfoniopropionate [DMSP], sulfide) by the microbial community during sulfide irruption events in the Salton Sea are discussed.

\section{MATERIALS AND METHODS}

Sample collection and processing. Sampling transects and station locations were chosen after observations of large differences in water color were made from a personal aircraft flying approximately $300 \mathrm{~m}$ above the lake (Fig. 1A). Exact locations and water depths of each sampling station are given in Fig. 1B and Table 1.

Water samples for DNA extraction and sulfide determination were collected at each station using a 5 l Niskin sample bottle. Subsamples (1 l) for DNA extractions were placed in acid-washed, autoclaved polypropylene bottles and stored $(<4 \mathrm{~h})$ on ice before gentle filtration onto Sterivex (0.2 $\mu \mathrm{m}$, Millipore) filter capsules by peristaltic pump. Prior to Sterivex filtration, water samples were filtered through $20 \mu \mathrm{m}$ nylon mesh to remove zooplankters and large protozooplankton (i.e. ciliates). Water volume (0.3 to 0.9 l) filtered through capsules was dependent on particulate matter concentration. Following filtration, excess water was expelled from capsules with empty sterile syringes, and the capsules were wrapped in sterile aluminum foil and frozen on dry ice. Capsules were later $(<24 \mathrm{~h})$ transferred to $-80^{\circ} \mathrm{C}$ until DNA extraction.

Water column profiles. Depth profiles of temperature, oxygen, and specific conductivity were measured at $1 \mathrm{~m}$ intervals using a YSI 85 meter and submersible probe. Water samples $(40 \mathrm{ml})$ for sulfide determination were collected at $2 \mathrm{~m}$ intervals. Each sample was collected in acid-washed glass vials containing an equal volume of sulfide antioxidant buffer (SAOB) solution (Orion) and placed immediately on ice. Sulfide concentrations were determined in the laboratory within $48 \mathrm{~h}$ using a sulfide-specific electrode (Orion) and appropriate standards.

DNA extraction and terminal restriction fragment length polymorphism (T-RFLP) analysis. Filters were removed from Sterivex capsules and cut in half using sterile razor blades and tweezers. DNA extraction from 1 filter half was done using the FastDNA SPIN Kit for Soil (Qbiogene) according to manufacturer's instructions. The second filter half was stored $\left(-80^{\circ} \mathrm{C}\right)$ as archived material. Extracted DNA was further purified using the Wizard SV Gel and PCR Clean-up System (Promega) and quantified using PicoGreen.

Archaeal and bacterial community structure was determined by T-RFLP (Avaniss-Aghajani et al. 1994). Duplicate $50 \mu \mathrm{l}$ PCR reactions were prepared and contained $50 \mathrm{ng}$ template DNA, $0.2 \mu \mathrm{M}$ forward primer, $0.2 \mu \mathrm{M}$ reverse primer, $1 \times$ Qiagen PCR buffer, $1.5 \mathrm{mM} \mathrm{MgCl} 2,200 \mu \mathrm{M}$ deoxynucleoside triphosphate (dNTP), 0.2 mM BSA (New England Biolabs [NEB]), and 2.5 U Taq DNA polymerase (Qiagen). Partial archaeal 16S rRNA genes were amplified using labeled (6-carboxyfluorescein [FAM], Eurofins MWG Operon) universal forward primer 519f (5'-CAG CMG CCG CGG TAA TWC-3'; Lane et al. 1985), the archaeal-specific reverse primer $1397 \mathrm{r}$ (5'-GTG TGC 


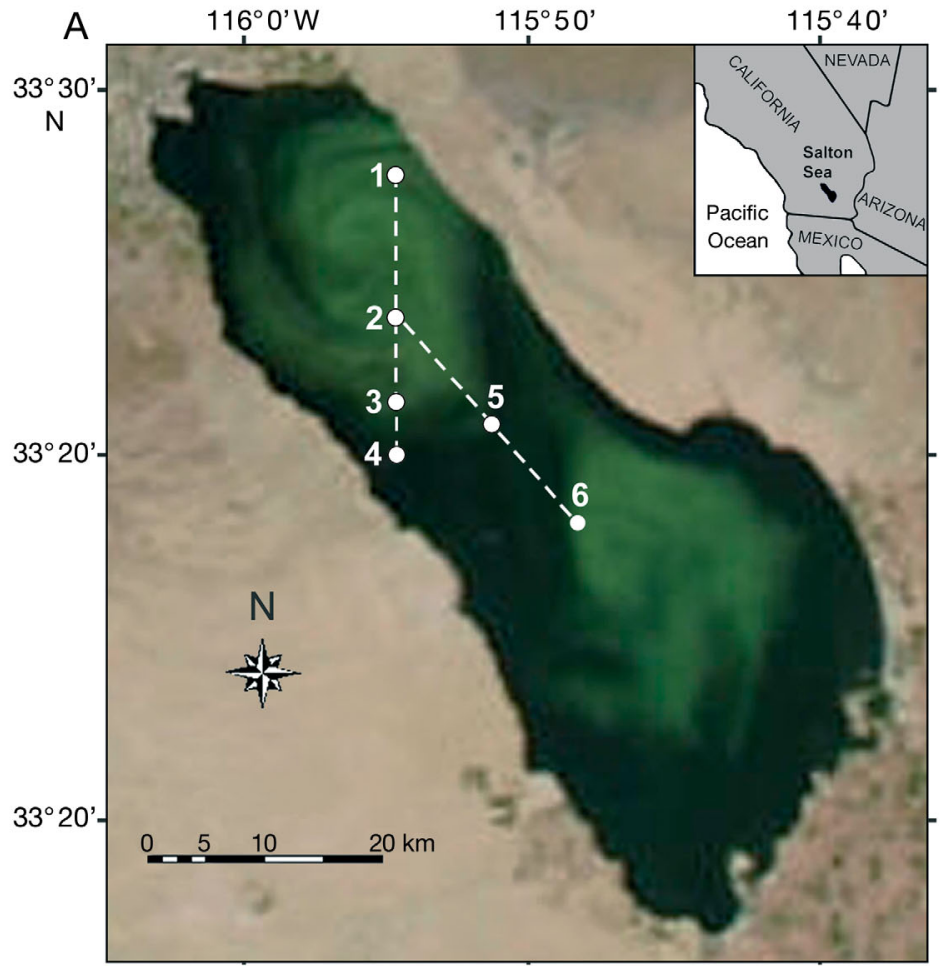

B
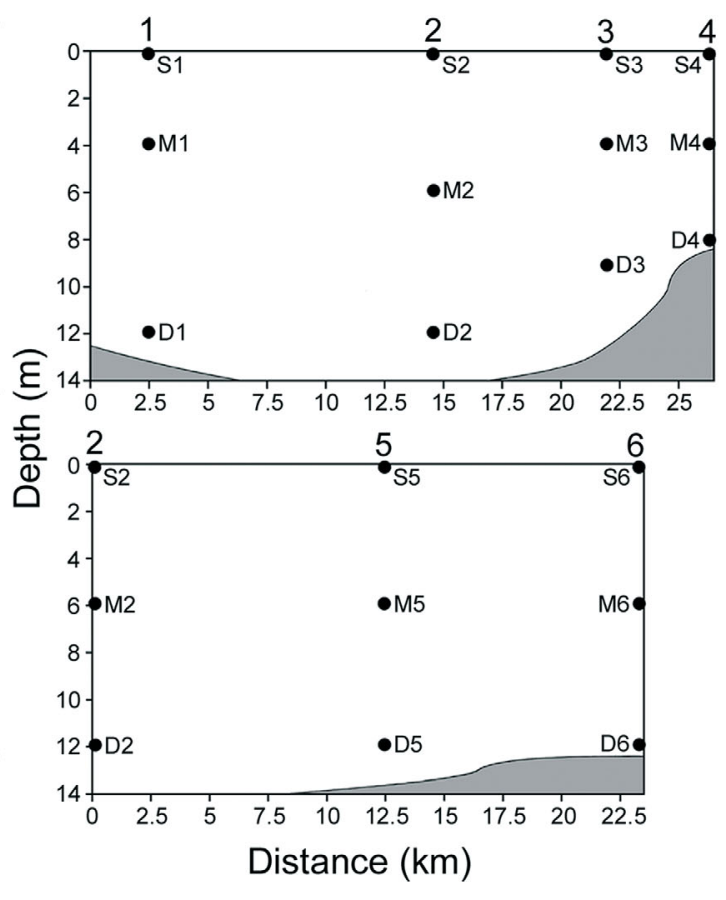

Fig. 1. (A) Map of the Salton Sea showing station locations (O) along 2 transects (dashed line) sampled for water column properties, microbial community structure, and phylogenetic composition. Background image is a moderate resolution imaging spectroradiometer (MODIS) Aqua satellite true color image collected on sampling date 3 September 2005. Patches of bright green-colored water are visible in both basins. Previous studies determined precipitating gypsum particles formed during sulfide oxidation change the optical properties of the water, causing distinct, bright green surface water masses to appear within sulfide-impacted regions. (B) Depth and location of all sampling stations along each transect. Shaded regions in (B) represent the approximate location of the lake bottom

AAG GRG CAG GGA-3'; J. A. Fuhrman unpubl. data), and the PCR amplification conditions: $3 \mathrm{~min}$

Table 1. Location and water depth of sampling stations

\begin{tabular}{|cccc|}
\hline Stn & Depth $(\mathrm{m})$ & Latitude $(\mathrm{N})$ & Longitude $(\mathrm{W})$ \\
\hline S1 & 0 & $33^{\circ} 28.33^{\prime}$ & $115^{\circ} 55.00^{\prime}$ \\
M1 & 4 & & \\
D1 & 12 & & \\
S2 & 0 & $33^{\circ} 25.00^{\prime}$ & $115^{\circ} 55.00^{\prime}$ \\
M2 & 6 & & \\
D2 & 12 & & \\
S3 & 0 & $33^{\circ} 21.58^{\prime}$ & $115^{\circ} 55.00^{\prime}$ \\
M3 & 4 & & \\
D3 & 9 & & \\
S4 & 0 & $33^{\circ} 20.00^{\prime}$ & $115^{\circ} 55.00^{\prime}$ \\
M4 & 4 & & \\
D4 & 8 & & \\
S5 & 0 & $33^{\circ} 21.00^{\prime}$ & $115^{\circ} 51.00^{\prime}$ \\
M5 & 6 & & \\
D5 & 12 & & \\
S6 & 0 & $33^{\circ} 18.00^{\prime}$ & $115^{\circ} 48.00^{\prime}$ \\
M6 & 6 & & \\
D6 & 12 & & \\
\hline
\end{tabular}

hot start at $95^{\circ} \mathrm{C}$, followed by 30 cycles (45 s denaturing at $94^{\circ} \mathrm{C}, 1 \mathrm{~min}$ annealing at $57^{\circ} \mathrm{C}, 2 \mathrm{~min}$ extension at $72^{\circ} \mathrm{C}$ ), and a final extension step of $5 \mathrm{~min}$ at $72^{\circ} \mathrm{C}$. Partial bacterial 16S rRNA genes were amplified using the FAM-labeled bacterial-specific forward primer $27 \mathrm{f}$ (5'-AGA GTT TGA TCM TGG CTC AG3'; Lane 1991), the universal reverse primer 1392r (5'ACG GGC GGT GTG TRC-3'; Lane 1991), and the PCR amplification conditions: 2 min hot start at $95^{\circ} \mathrm{C}$, followed by 30 cycles ( $45 \mathrm{~s}$ denaturing at $95^{\circ} \mathrm{C}, 45 \mathrm{~s}$ annealing at $55^{\circ} \mathrm{C}, 90 \mathrm{~s}$ extension at $72^{\circ} \mathrm{C}$ ), and a final extension step of $7 \mathrm{~min}$ at $72^{\circ} \mathrm{C}$. Amplicon sizes were checked using gel electrophoresis $(0.8 \%$ agarose, $30 \mathrm{~min}$ at $80 \mathrm{~V}$ ) and visualized after SYBR Gold (Molecular Probes) staining.

PCR products were quantified (PicoGreen) and duplicate $40 \mu \mathrm{l}$ restriction digest reactions containing $50 \mathrm{ng}$ PCR product, $5.0 \mu \mathrm{l} 1 \times$ enzyme buffer $(20 \times, \mathrm{NEB})$, $0.5 \mu \mathrm{lBA}\left(10 \mathrm{mg} \mathrm{ml}^{-1}\right)$, and $0.5 \mathrm{U}$ of restriction enzyme (NEB) were prepared for each sample and digested for $8 \mathrm{~h}$. Restriction enzymes HhaI, DdeI, and DpnI were used for Archaea, and HhaI, HaeIII, and RsaI were used for Bacteria. Digestion products were 
purified and concentrated (Montage PCR Centrifugal Device, Millipore), quantified (PicoGreen), and diluted to an equivalent DNA concentration. Products were run in duplicate on an ABI PRISM 3100 Genetic Analyzer (Applied Biosystems) at the Genomics Technology Support Facility (GTSF) at Michigan State University. Electropherograms were analyzed using GeneScan v. 3.1 software (Perkin-Elmer).

T-RFLP statistical analysis. Terminal restriction fragment (TRF) peaks $\geq 50$ fluorescent units (e.g. above background), and constituting $\geq 0.5 \%$ of total sample peak area, were manually aligned by comparison to an internal size standard. Duplicate T-RFLP profiles were compared and non-replicated TRF peaks were removed from further analyses. Replicated TRF peak areas were averaged and relative peak areas of each TRF were determined by dividing individual TRF peak areas by total sample area (based on replicated TRF peaks only).

Microbial community structure patterns were evaluated using hierarchal cluster and non-metric multidimensional scaling (NMDS) analysis (Clarke 1993). Hierarchal cluster analysis was performed on TRF relative abundance and presence/absence data using the Bray-Curtis (BC) similarity index and flexible-beta linkage ( $\beta=-0.25$; McCune et al. 2002). NMDS is an ordination technique that plots samples as points in low-dimensional space, while attempting to maintain the relative distances between points as close as possible to the actual rank order of similarities between samples. Thus, sampling stations with similar community structures are plotted closer together in ordination space. A stress factor is calculated for each NMDS ordination and indicates how well plotted configurations of sample distances agree with original rank orders calculated from the similarity matrices. NMDS analysis of T-RFLP profiles was performed using previously calculated BC indices for TRF relative abundances.

Relationships between microbial community structure and environmental variables were examined using the BEST procedure (Clarke \& Warwick 2001), which calculates modified Spearman rank correlation coefficients $\left(\rho_{\mathrm{s}}\right)$ between NMDS configurations and Euclidean similarity matrices of all possible environmental variable combinations. Sulfide concentrations were log-transformed before calculating Euclidean similarities, whereas dissolved oxygen and temperature values were not transformed. Cluster analysis was done using XLStat (AddinSoft SARL) and all NMDS calculations were performed using PRIMER v. 6.0 (Primer-E).

Clone libraries and phylogenetic analysis. Archaeal and bacterial 16S rRNA gene clone libraries were constructed from 2 stations (S5 and M6) that differed in community structure (e.g. T-RFLP patterns) and environmental condition (e.g. sulfide concentration). PCR conditions and primers used for cloning were the same as those used for T-RFLP. PCR products were cloned using the PCR CloningPlus Kit (Qiagen), and blue/ white screening of cloned plasmids was done using Luria-Bertani (LB) agar plates containing $100 \mathrm{\mu g} \mathrm{ml}^{-1}$ ampicillin, $80 \mu \mathrm{g} \mathrm{ml}^{-1} \mathrm{X}$-gal, and $50 \mu \mathrm{M}$ Isopropyl- $\beta$-Dthiogalactoside (Teknova). Picked transformants were grown overnight in $1.6 \mathrm{ml} \mathrm{LB}$ broth containing 0.075 $\mathrm{mg} \mathrm{ml}^{-1}$ ampicillin, and plasmid DNA was extracted using the QuickClean 5M Miniprep Kit (GenScript) according to manufacturer's instructions. Approximately $500 \mathrm{ng}$ of plasmid DNA was sequenced at the University of California Berkeley DNA sequencing facility using T7/M13 sequencing primers. Average partial archaeal and near full-length bacterial sequences were 890 and 1374 nucleotides, respectively.

A dominant ( $76 \%$ in Stn S5 and $100 \%$ in Stn M6) archaeal phylotype was present in both clone libraries. Therefore, additional cloning and sequencing from Stn M6 was done using a second primer set, 8f $\left(5^{\prime}\right.$-TCC GGT TGA TCC TGC C-3') and 1492r (5'-GGC TAC CTT GTT ACG ACT T-3') (Sørensen et al. 2004b), using the PCR amplification conditions: 3 min hot start at $94^{\circ} \mathrm{C}$, followed by 30 cycles $\left(45 \mathrm{~s}\right.$ denaturing at $94^{\circ} \mathrm{C}$, $45 \mathrm{~s}$ annealing at $58^{\circ} \mathrm{C}, 3$ min extension at $72^{\circ} \mathrm{C}$ ), and a final extension step of $5 \mathrm{~min}$ at $72^{\circ} \mathrm{C}$. PCR products were cloned and sequenced as previously described and had an average length of 1450 nucleotides.

Sequence ends were trimmed and edited using Sequencher v. 4.7 (Gene Codes, Ann Arbor, MI), and checked for chimeras using Mallard (Ashelford et al. 2006) and Bellerophon (Huber et al. 2004). Suspect sequences were removed prior to further analysis. Phylotypes ( $\geq 97 \%$ sequence similarity) were determined using DOTUR (Schloss \& Handelsman 2005). A single representative sequence of each phylotype was included in the alignments. Edited sequences were compared to previously deposited sequences using the RDP v. 10 Seqmatch (Cole et al. 2009) and NCBI's BLASTN (Altschul et al. 1990) online tools. Multiple sequence alignments of closest-matched isolate, environmental sequences, and clone sequences from the present study were performed using CLUSTAL_X v. 1.81 (Thompson et al. 1997).

Neighbor-joining (NJ) trees of archaeal and bacterial sequences, with the Jukes-Cantor nucleotide substitution correction and 1000 distance bootstrap replicates, were constructed using PAUP* ${ }^{*}$ v. 4.0 beta 10 (Swofford 2003). Phylogenetic trees were exported and edited using TreeView v. 1.6.0 (Page 1996). Phylogenetic trees were also constructed using maximum parsimony (HKY85 model) and maximum likelihood methods, and resulting tree topologies were similar to those gener- 
ated using NJ methods (trees not shown). Clone library coverage was calculated using Good's index $(C)$, and richness $\left(S_{\mathrm{Chao1}}\right)$ and rarefaction curves were calculated using DOTUR.

Identification of bacterial TRFs. Putative phylogenetic identities of dominant bacterial TRFs were determined by in silico digestion of clone sequences with HhaI using Sequencher v. 4.7 and matching observed TRFs from T-RFLP profiles using the program TRiFLe (Junier et al. 2008). A length discrepancy cut-off value of $\leq 2$ nucleotide base pairs was applied to all matches. The relative abundance of bacterial phylogenetic groups at each station was estimated by dividing matched TRF peak areas by the sum of all matched TRF peak areas.

Nucleotide sequence accession numbers. 16S rRNA gene sequences were deposited in the GenBank database under accession numbers FJ656253 to FJ656258 (Archaea) and FJ973577 to FJ973603 (Bacteria).

\section{RESULTS}

\section{Water column properties}

Sampling stations were easily distinguished by comparisons of water temperature and sulfide concentration (Fig. 2). Except for 2 stations (S6 and D2), stations with high sulfide concentration also had similar water temperatures (Fig. 2). In contrast, evidence of daily warming was found at stations with low sulfide concentration, with slightly higher temperatures being found in surface waters. Dissolved oxygen concentration and specific conductivity varied little by

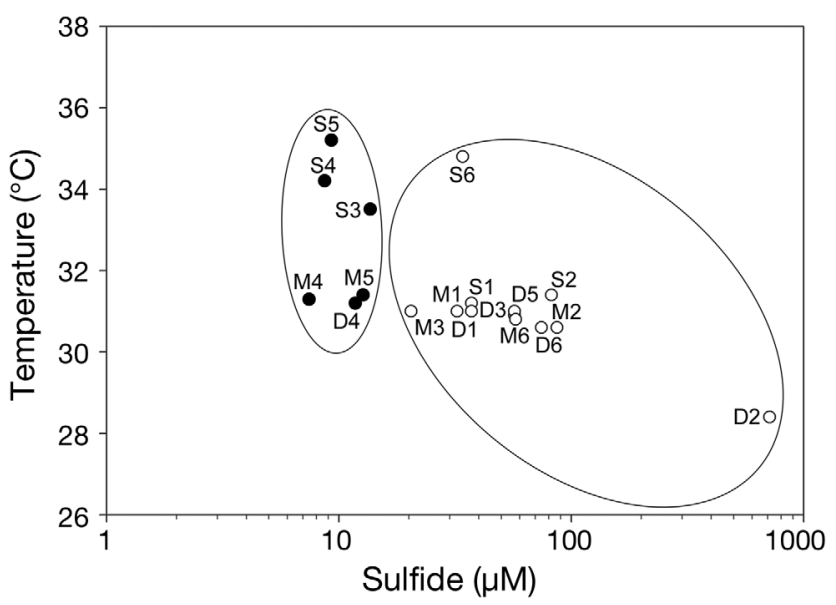

Fig. 2. Property-property plot of water temperature and logtransformed sulfide concentration quantified at each station. Low-sulfide $(7.4$ to $13.6 \mu \mathrm{M})$ stations $(\bullet)$ and high-sulfide (20.5 to $713 \mu \mathrm{M}$ ) stations (O) are each encircled by an ellipse. Station labels are the same as those in Fig. 1B station, with an increase in oxygen concentration being found only at some stations (see Tiffany et al. 2007c for profiles).

\section{Microbial community structure patterns}

A total of 24 to 36 archaeal and 60 to 106 bacterial TRFs were recovered from sampling stations using 3 different restriction enzymes. Cluster and NMDS patterns were similar among restriction enzymes and therefore only results from HhaI are presented. A dominant archaeal TRF that comprised 39 to $91 \%$ of relative peak area was recovered from all samples. The relative abundances of other archaeal and bacterial HhaI TRFs were distributed relatively evenly, with most TRFs accounting for $\leq 6 \%$ of total relative peak area. Cluster analysis revealed that stations with similar sulfide concentration had similar community structure, and similarity values between and within main sample groupings were similar between both microbial groups (Fig. 3). NMDS ordination patterns closely followed cluster analysis results (Fig. 4). Two-dimensional NMDS ordinations were well supported, indicated by low stress values for both microbial groups, and sample configurations were best correlated with sulfide concentration (Fig. 4).

\section{Phylogenetic diversity}

A total of 126 archaeal and 53 bacterial clones were sequenced and classified from 2 sampling stations. Only 6 archaeal phylotypes were identified using 2 primer sets, and rarefaction analysis indicated the majority of estimated diversity was recovered (Fig. 5). In contrast, a total of 27 bacterial phylotypes were identified from both libraries, but coverage and estimated richness values of individual bacterial clone libraries indicate stations were under-sampled (Stn S5: $C=61 \%, S_{\text {Chao1 }}=28 ;$ Stn M6: $\left.C=40 \%, S_{\text {Chao1 }}=46\right)$. Rarefaction analysis of combined bacterial libraries also indicated expected richness was higher than was recovered by sequencing efforts at the species $(97 \%$ similarity) level, but a large fraction of sequences at the phylum level (80\% similarity) were recovered (Fig. 5).

Partial 16S rRNA sequence phylotypes (519f-1397r primer set) matched exclusively to sequences recovered from a clone library constructed from Salton Sea surface $(0$ to $1 \mathrm{~cm}$ ) sediment (Swan et al. 2010), and only 1 archaeal phylotype was recovered from the high-sulfide station (Table 2). These sediment clone sequences were recovered only from surface sediment, classified within the euryarchaeal Marine Benthic Group (MBG)-D, and were most similar to environ- 


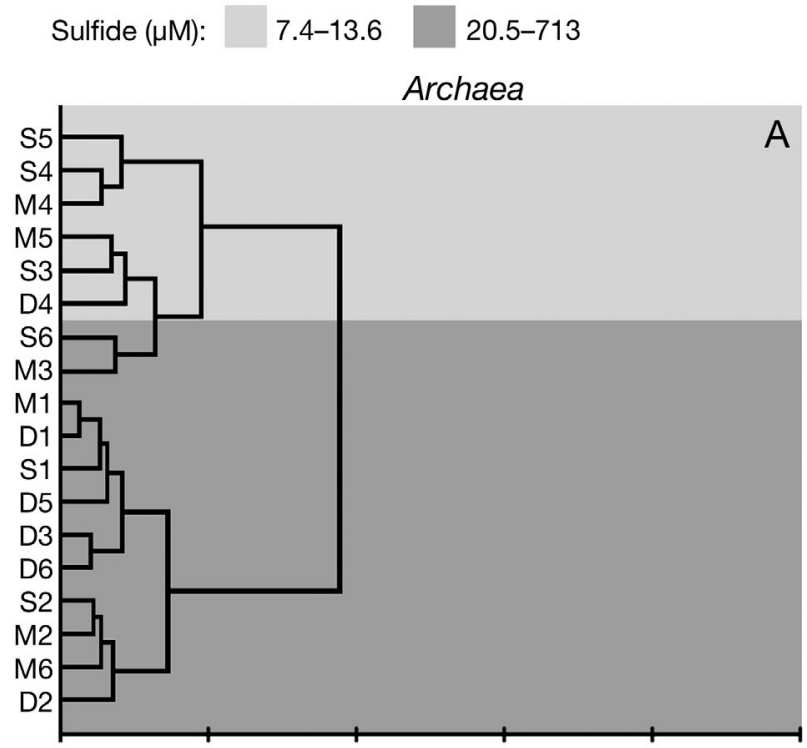

Bacteria

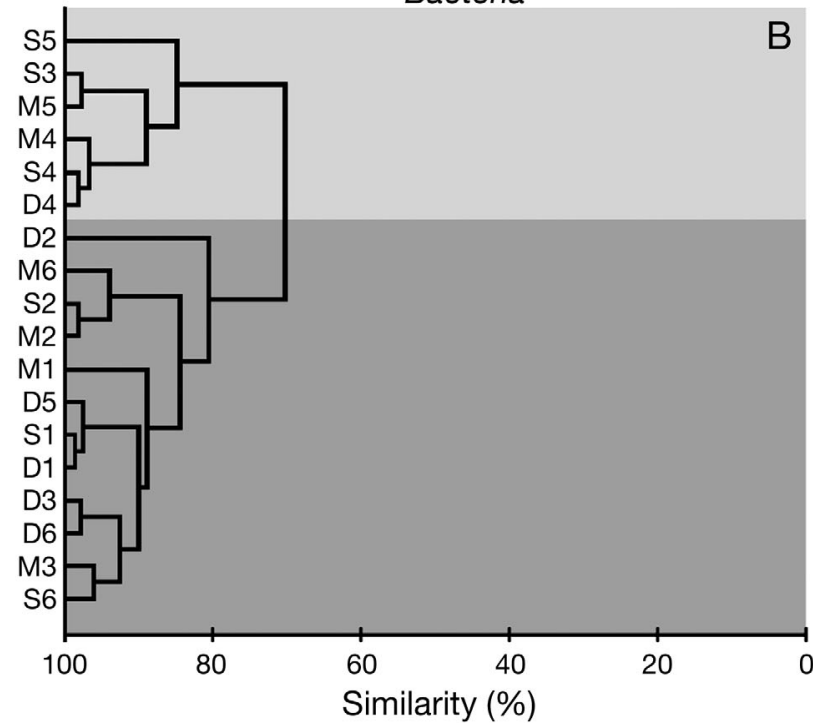

Fig. 3. Hierarchical cluster analysis of terminal restriction fragment length polymorphism (T-RFLP) profiles for (A) Archaea and (B) Bacteria using relative abundances of terminal restriction fragments (TRFs). Bray-Curtis similarity index was used to generate distance matrices and flexible beta $(\beta=-0.25)$ for determining linkages. Stations are listed on the $y$-axes, and differences in sulfide concentration between sample groupings are indicated by shaded areas

mental sequences from methanogenic sediments. Additional sequencing from the high-sulfide station (M6) using a second primer set (8f-1492r) revealed 2 additional phylotypes that matched closely to methanogen sequences belonging to Methanococcoides spp. (Orphan et al. 2008), Methanohalophilus spp. (Orphan et al. 2008), and Methanosarcinales spp. (Mochimaru et al. 2007) isolated from hypersaline

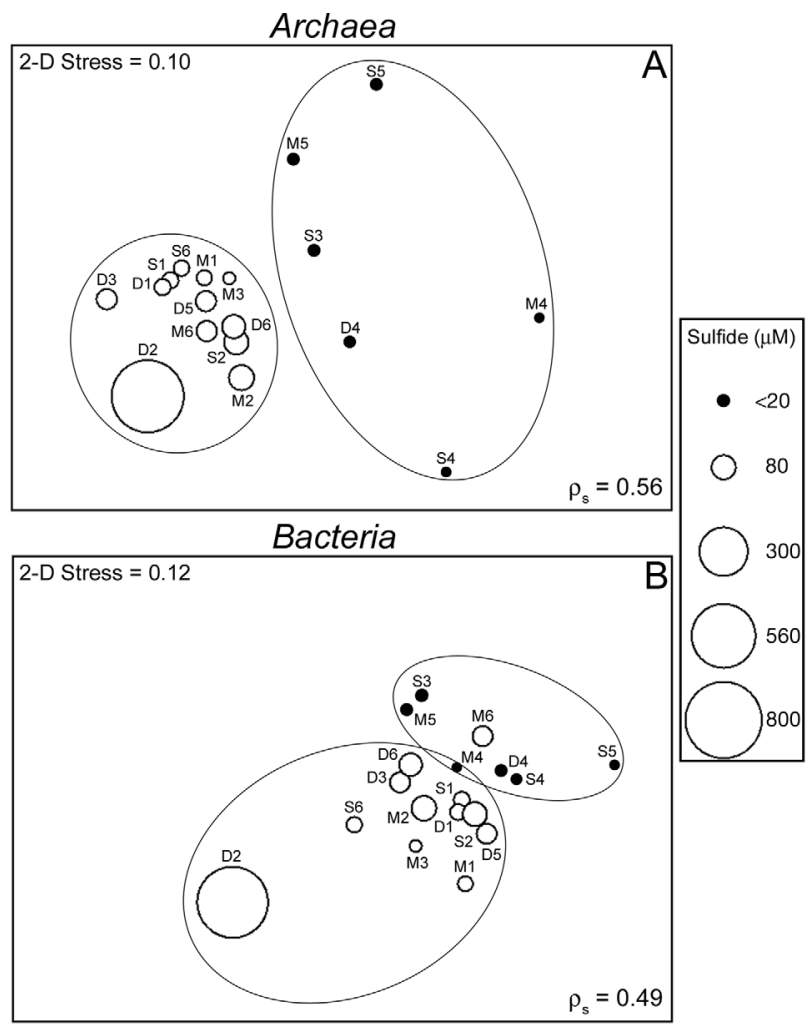

Fig. 4. Non-metric multi-dimensional scaling (NMDS) analysis of (A) Archaea and (B) Bacteria community structure, based on Bray-Curtis similarities calculated using the relative abundance of terminal restriction fragments (TRFs) obtained by restriction with HhaI. Corresponding sulfide concentrations are represented as circles in each NMDS plot. Ellipses encircle sampling groups previously determined by cluster analysis (see Fig. 2). NMDS topology and stress values from TRF data generated using other restriction enzymes were similar (data not shown). 2-D: 2-dimensional, $\rho_{\mathrm{s}}$ : modified Spearman rank correlation coefficient

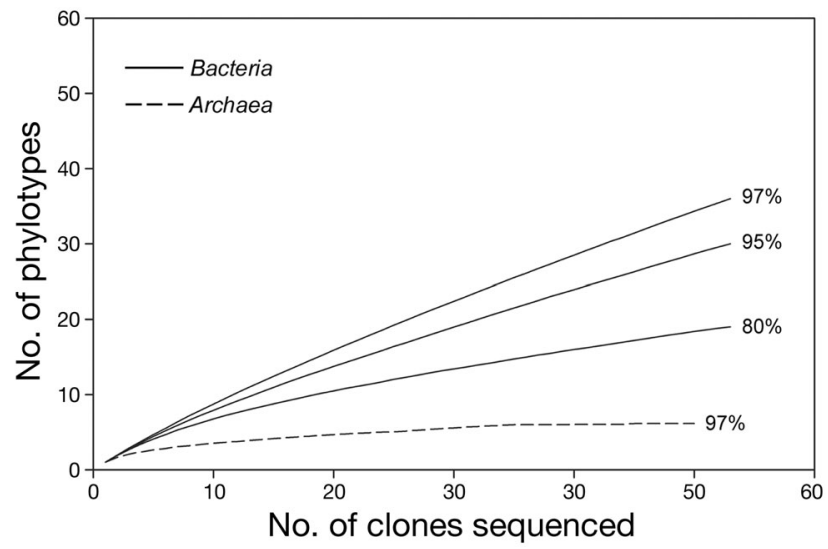

Fig. 5. Rarefaction curves of phylotype ( $\geq 97 \%$ sequence similarity) richness for combined bacterial and archaeal 16S rRNA gene clone libraries from 2 sampling stations (S5 and M6). Bacterial rarefaction curves at 3 different levels of sequence similarity are presented 
Table 2. Frequency and closest GenBank database matches to archaeal 16S rRNA gene sequences recovered from the Salton Sea. PCR primers used for amplification: (1) 519f-1397r and (2) 8f-1492r. Clone names and accession numbers of closest sequence matches were identified using the RDP v. 10 Seqmatch and NCBI BLASTN online search tools. Matches to environmental sequences and isolates are provided when possible. Unc: uncultured; euryarch: euryarchaeote

\begin{tabular}{|c|c|c|c|c|c|c|}
\hline Stn & Primers & Clone name & $\begin{array}{c}\text { Accession } \\
\text { no. }\end{array}$ & $\begin{array}{c}\text { Library } \\
(\%)\end{array}$ & Closest match & $\begin{array}{c}\text { Similarity } \\
(\%)\end{array}$ \\
\hline \multicolumn{7}{|c|}{ Low-sulfide (50 clones) } \\
\hline \multirow[t]{4}{*}{ S5 } & 1 & SS_WC_01 & FJ656253 & 76 & Unc archaeon SS078 (EU329815) & 99 \\
\hline & 1 & SS_WC_02 & FJ656254 & 17 & Unc archaeon SS064 (EU329801) & 99 \\
\hline & 1 & SS_WC_03 & FJ656255 & 5 & Unc archaeon SS078 (EU329815) & 91 \\
\hline & 1 & SS_WC_04 & FJ656256 & 2 & Unc archaeon SS078 (EU329815) & 94 \\
\hline \multicolumn{7}{|c|}{ High-sulfide (45 clones) } \\
\hline M6 & 1 & SS_WC_01 & FJ656253 & 100 & Unc archaeon SS078 (EU329815) & 99 \\
\hline \multicolumn{7}{|c|}{ High-sulfide (31 clones) } \\
\hline \multirow[t]{6}{*}{ M6 } & 2 & SS_WC_05 & FJ656257 & 54 & Unc euryarch ET5_1D11 (EU585965) & 97 \\
\hline & & & & & Methanococcoides spp. (EU585968) & 98 \\
\hline & & & & & Methanococcoides spp. (Y16946) & 97 \\
\hline & 2 & SS_WC_06 & FJ656258 & 46 & Unc archaeon MOB7-2 (DQ841237) & 98 \\
\hline & & & & & Methanohalophilus spp. (AY290717) & 97 \\
\hline & & & & & Unc Methanohalophilus spp. (EU731575) & 5) 96 \\
\hline
\end{tabular}

microbial mats and deep subsurface water from gas fields, respectively (Table 2).

Nearly half of bacterial phylotypes (41\%) belonged to the Proteobacteria, and most were similar (>96\% similarity) to sequences of Bacteria capable of utilizing sulfur compounds for growth (Fig. 6A). Within the Gammaproteobacteria, 1 phylotype was similar to Thiomicrospira chilensis (Brinkhoff et al. 1999) and another grouped with the photoautotrophic purple sulfur bacteria Marichromatium sp. (Serrano et al. 2009) and Halochromatium sp. Six phylotypes were phylogenetically associated with the Alphaproteobacteria family Rhodobacteraceae (purple non-sulfur bacteria), including Maritimibacter alkaliphilus (Lee et al. 2007), Rhodovulum sulfidophilum (Hiraishi \& Ueda 1994), and uncultured relatives of Rhodobacter, Roseobacter, and Sulfitobacter genera. Interestingly, the isolate Maritimibacter alkaliphilus is described as being strictly aerobic, but the majority of the water column at all stations was anoxic. Additional phylotypes matched clone sequences of Beta- and Deltaproteobacteria.

Several phylotypes matched non-proteobacterial lineages, including Chlorobi (green-sulfur bacteria), Bacteroidetes, Firmicutes, Chloroflexi, and Actinobacteria (Fig. 6B). Members of these groups are known to utilize reduced sulfur compounds or are often abundant in anoxic marine and saline lake sediments. Two cyanobacterial phylotypes were more similar to Synechococcus spp. sequences detected in the Red Sea (Fuller et al. 2003) and ocean waters (e.g. isolate WH8101) than one previously reported from the Salton Sea (Carmichael \& Li 2006) (Fig. 6C).

\section{Microbial composition patterns}

Relative abundance estimates of phylogenetic groups based on matched TRF abundances or clone library frequencies were similar at both stations where cloning and sequencing was done (S5 and M6), whereas differences in abundances of some groups were found (Fig. 7). Actinobacteria, Gammaproteobacteria, and Chlorobi were all greater in abundance at high-sulfide stations than low-sulfide stations. Cyanobacteria were the most abundant phylogenetic group at most stations (19 to $47 \%$ ), followed by Bacteroidetes and Alphaproteobacteria (Fig. 8). Strong trends in abundance changes with depth were not found between all stations sampled.

\section{DISCUSSION}

\section{Community structure and bacterial diversity as a function of sulfide concentration}

Sulfide concentration was found to be correlated with changes in microbial community structure, which agrees with previous studies documenting localized shifts in Salton Sea phytoplankton (Tiffany et al. 2007a) and zooplankton (Tiffany et al. 2002) communities during sulfide irruption events. While changes in microbial community structure were correlated with sulfide concentration, sulfide levels were relatively high at all stations sampled, indicating that other irruption events may have occurred prior to our sampling. A large fish kill (>3 million) was documented in late August 2005, a few weeks prior to 


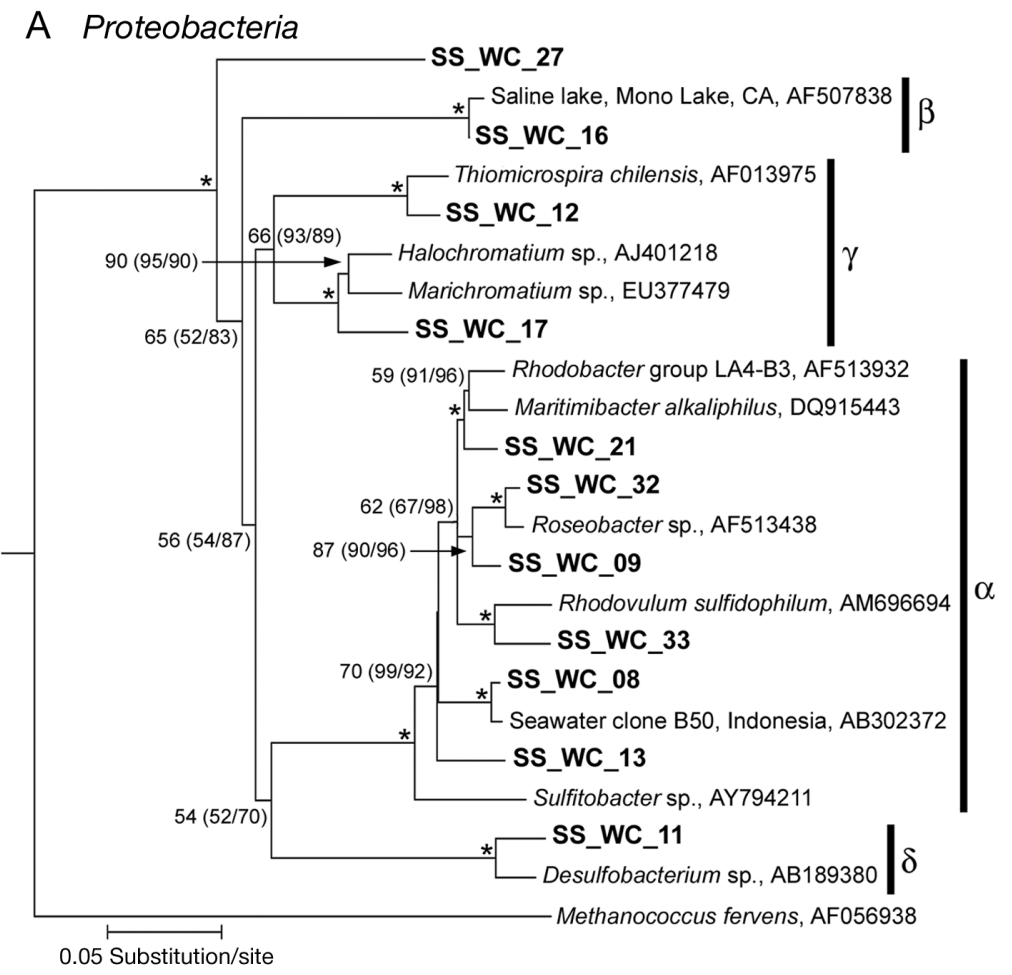

\section{B Non-Proteobacteria}

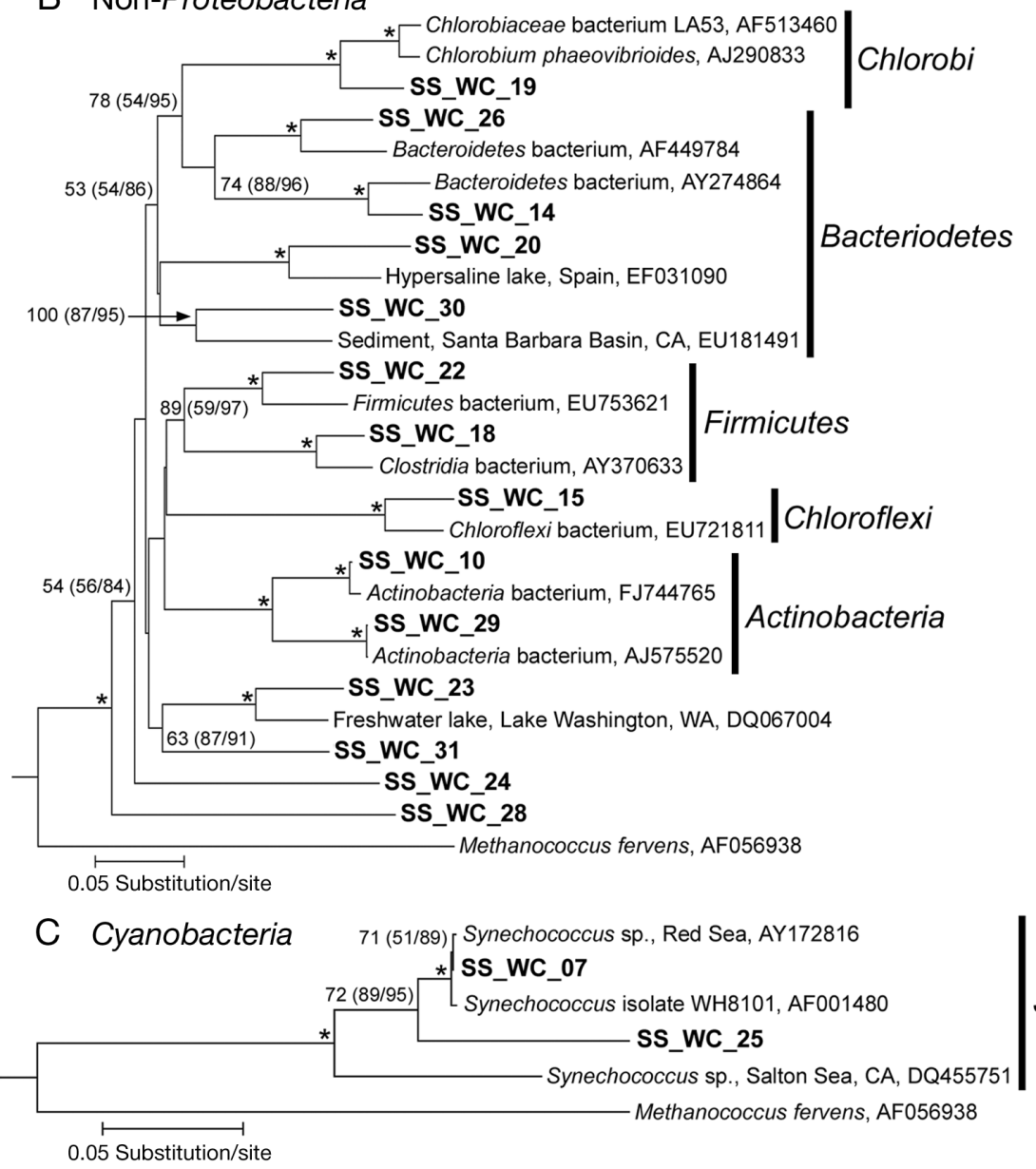

Fig. 6. Phylogenetic relationships between near full-length bacterial 16S rRNA gene sequences from Salton Sea (SS) clone libraries (boldface, values are clone number), and previously reported environmental and isolate sequences of (A) Proteobacteria, (B) nonProteobacteria, and (C) Cyanobacteria. Trees were constructed using the neighbor-joining algorithm with Jukes-Cantor-corrected DNA distances. Bootstrap values for Jukes-Cantor (1000 replicates), maximum parsimony (1000 replicates), and maximum likelihood (100 replicates) $\geq 50$ are indicated at nodes outside and inside parentheses, respectively. Nodes with $\left(^{*}\right)$ indicate bootstrap values $\geq 95$ for all 3 tree-building methods. Scale bars represent $5 \%$ sequence difference, and Methanococcus fervens was used as the outgroup. WC: water column 


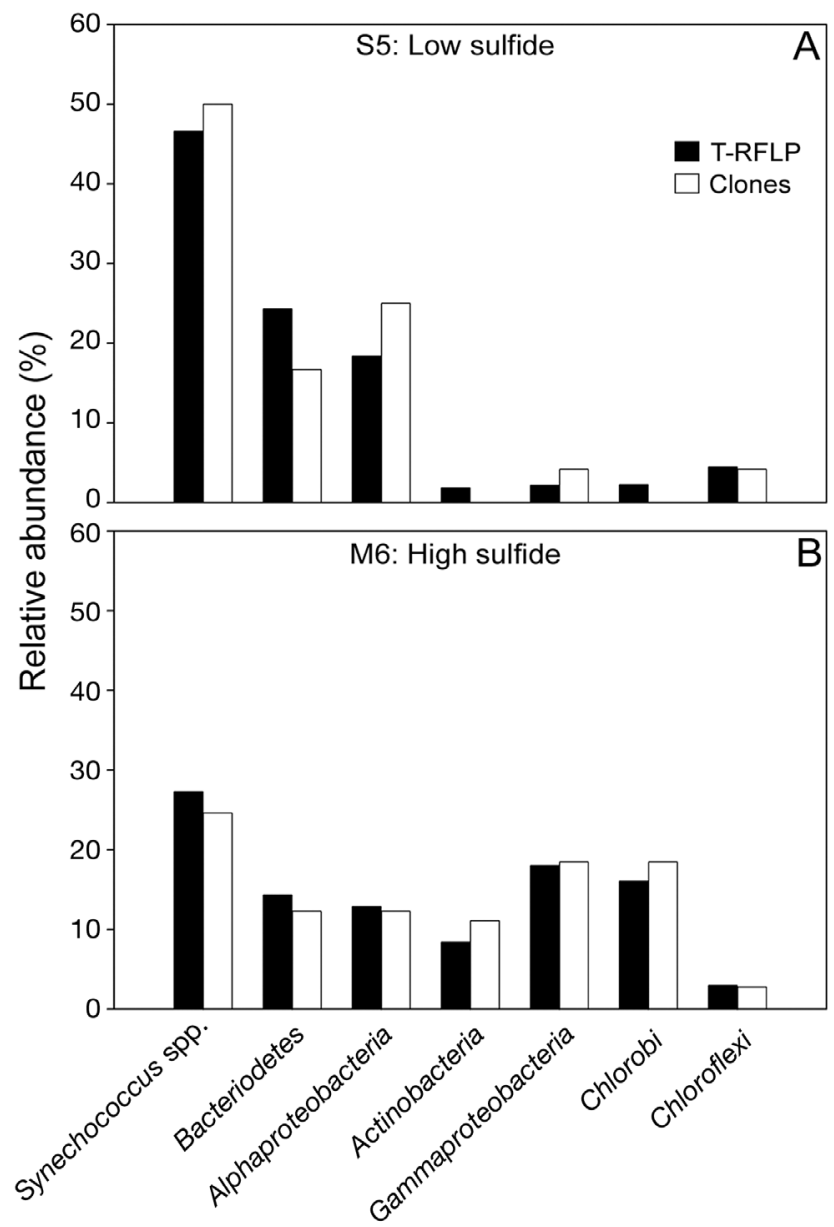

Fig. 7. Comparisons between relative abundances of select bacterial phylogenetic groups quantified by terminal restriction fragment (TRF) matching and clone library frequency at 2 sampling stations, (A) S5 and (B) M6

our sampling. Also, Watts et al. (2001) estimated that hypoxic/anoxic conditions could remain in surface waters of the Salton Sea for several days to weeks after an irruption event. This is primarily a function of sulfide-rich (>1 mM) bottom waters acting as source water during mixing, reduced solubility of oxygen in the warm (30 to $35^{\circ} \mathrm{C}$ ) hypersaline water column (Watts et al. 2001), and the relatively slow rate of abiotic sulfide oxidation in saline waters (Millero et al. 1987). Therefore, it is not possible to separate the factors of sulfide concentration and hypoxia/ anoxia in causing mortality of plankton, benthic invertebrates, and fish populations. However, it was determined in the present study that oxygen concentration was less important in explaining differences in microbial community structure between stations.

Oxidation of sulfide by microbes in the water column is likely an important process in the Salton Sea. Analysis of bacterial diversity revealed several lineages related to various known photoautotrophic and chemoautotrophic (i.e. sulfide-oxidizing) groups commonly
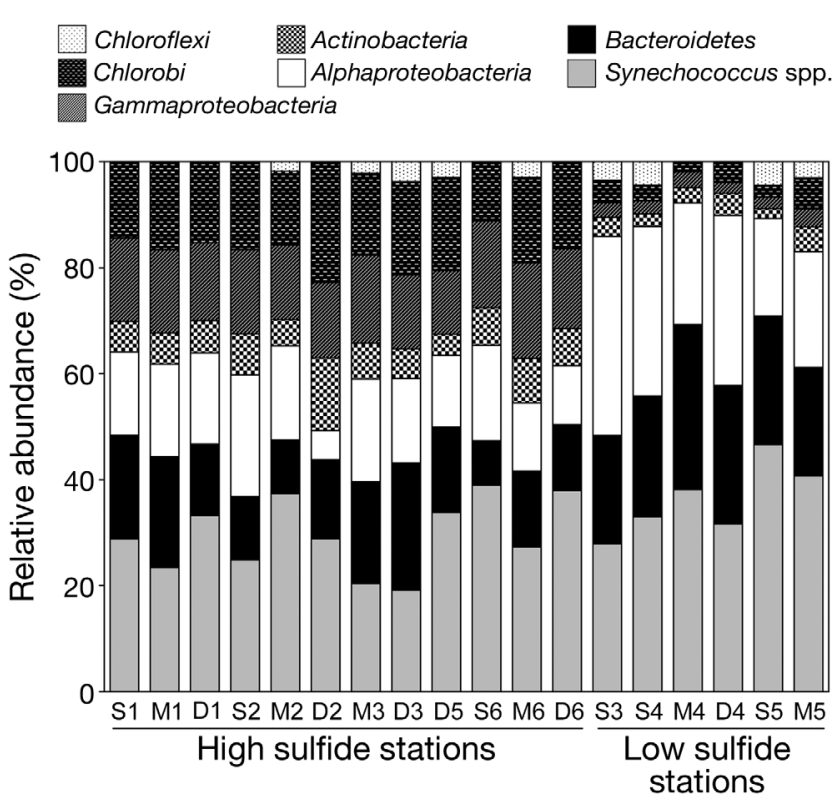

Fig. 8. Relative abundance of bacterial phylogenetic groups calculated from terminal restriction fragment (TRF) peak area frequencies at each sampling station. TRFs were putatively assigned to phylogenetic groups by comparison to expected TRFs from 16S rRNA clone library sequences

found in marine waters and anoxic sediments. Differences in bacterial diversity between stations could be explained by examining the physiological adaptations (i.e. sulfide tolerance) and metabolic requirements of these various groups. For example, both the gammaproteobacterial purple (i.e. Halochromatium sp.) and green sulfur bacteria (i.e. Chlorobi) were more abundant at high-sulfide stations, whereas the alphaproteobacterial purple non-sulfur (i.e. Rhodobacteraceae) bacteria were more abundant at low-sulfide stations. Purple non-sulfur bacteria are less tolerant of sulfide and may not compete well with the more metabolically flexible, sulfide-utilizing sulfur bacteria in the Salton Sea (Bryant \& Frigaard 2006). In addition, Chlorobi require light for anoxygenic photosynthesis and compete directly with other phototrophs for this resource, or with the presence of light-attenuating material. During sulfide irruption events, $>90 \%$ of phytoplankton biomass can be lost from the water column, and watercolumn mixing brings sulfide into the light-saturated surface waters, which together may act to stimulate Chlorobi growth. Little information exists on the seasonal dynamics of bacterial communities in the Salton Sea, so the abundance and distribution of these groups when sulfide is not present remains unknown. A recent study of water column bacteria diversity in the Salton Sea also found higher abundances of these groups after a recent fish kill when compared to other times of year (Dillon et al. 2009). 


\section{Archaeal diversity and the water-column sulfur cycle}

Water column archaeal diversity was lower than for Bacteria, and also lower than archaeal diversity found in profundal sediments of the Salton Sea (107 phylotypes out of 271 clones; Swan et al. 2010). Although differences in community structure between stations were detected, only 4 phylotypes from 16S rRNA sequencing were recovered using the same primer set used for T-RFLP. Therefore, a majority of TRFs that differentiated stations were not identified. This discrepancy could be explained by the low abundances of most archaeal TRFs, the relative dominance of samples by only a few TRFs, and cloning bias due to lower archaeal 16S rRNA gene copy numbers. Because archaeal 16S rRNA gene sequence diversity was limited, we were unable to further distinguish stations by clone sequence frequency or matched TRFs as was done for Bacteria. 16S rRNA gene sequences recovered using a second primer set (8f-1492r) were not detected by the original primer set (519f-1397r), indicating the potential for discovering additional archaeal diversity in this environment.

Several potential metabolic roles of Archaea recovered from the anoxic, sulfidic water column are suggested from information from closest-neighbor $16 \mathrm{~S}$ rRNA gene sequence matches. Partial archaeal 16S rRNA sequences recovered using one primer set (519f-1397r) matched closely (91 to 99\%) to Salton Sea surface $(0$ to $1 \mathrm{~cm}$ ) sediment sequences (clones SS078 and SS064) and grouped within the MBG-D, whereas full-length sequences from the present study matched (96 to $98 \%$ ) to Methanohalophilus spp., Methanococcoides spp., and Methanosarcinales spp. sequences previously recovered from hypersaline mats (Orphan et al. 2008), solar salterns (Sørensen et al. 2004a), and other anoxic, sulfidic environments. Isolates of these methanogenic lineages are obligate methylotrophs that metabolize 'non-competitive' compounds such as methanol, methylamines (i.e. trimethylamine), and methylsulfides, including dimethylsulfide (DMS; Oremland et al. 1982, Kiene et al. 1986). DMS is a commonly occurring volatile sulfur compound often formed via microbial reduction of DMSP, a precursor compound that is released by grazed or senescent phytoplankton cells (Vairavamurthy et al. 1985, Kiene et al. 2000). Significant levels of DMSP and DMS have been detected in the Salton Sea, but were low or undetectable in sulfiderich bottom waters and surface waters after a sulfide irruption event, which could be explained by increased microbial utilization (Reese \& Anderson 2009). No Methanococcoides spp. isolates are known to utilize methylsulfides such as DMS and instead utilize compounds such as trimethylamine. One potential source of trimethylamine in the water column is trimethylamine
$\mathrm{N}$-oxide, which is abundant in fish tissue (Niizeki et al. 2003) and is reduced by a wide variety of Bacteria commonly found in marine and freshwater environments (Barrett \& Kwan 1985). Large (ca. 3 to 5 million) fish kills that occur due to irruption events could provide significant amounts of trimethylamine to microbial communities in the Salton Sea. Another significant source of trimethylamine is from the breakdown of glycine betaine, an organic solute accumulated by halophilic and halotolerant microbes for osmoregulation (Oren 1990). Although archaeal populations detected in the water column may have originated from resuspended sediment or anoxic bottom waters, we speculate that the mixing of reduced sulfur compounds into surface waters during sulfide irruptions may expand their ecological niche in the Salton Sea.

\section{Potential roles of Cyanobacteria in sulfide irruption events}

The abundance of 16S rRNA gene sequences and TRFs belonging to Synechococcus spp. suggest this bacterial lineage was dominant at most stations. Previous studies of Salton Sea Cyanobacteria also recovered Synechococcus spp. 16S rRNA gene sequences similar to marine isolates, and they comprised a significant fraction of picophytoplankton biomass (Wood et al. 2002, Carmichael \& Li 2006). Filamentous types (e.g. Oscillatoria spp.) were reported to be abundant, and evidence of an increase in their abundance was documented during a seasonal study of eukaryotic phytoplankton (Tiffany et al. 2007a). Because water samples collected in the present study were pre-filtered $(20 \mu \mathrm{m})$, filamentous and larger-celled Cyanobacteria may have been excluded in samples used for PCR amplification. Although sulfide can inhibit oxygenic photosynthesis, sulfide tolerance of Cyanobacteria is shaped to some degree by environmental exposure (Miller \& Bebout 2004), and sulfide may also be utilized during anoxygenic growth, thus contributing to the oxidation of sulfide in some environments (Luo \& Mitsui 1996). Another consequence of increased $C y$ anobacteria abundance after sulfide irruption events may be elevated exposure of bird populations to cyanotoxins (i.e. microcystins). In addition to fish kills, numerous bird die-offs have occurred at the Salton Sea, and their exact causes have not yet been identified (Reifel et al. 2002). Recently, a Synechococcus sp. (strain SS-1) was isolated from the Salton Sea that is capable of producing microcystins (Carmichael \& Li 2006). This is the first report of a marine-type Synechococcus sp. producing cyanotoxins, although concentrations measured from field samples were not sufficient to elicit acute toxicity in mammals. 


\section{CONCLUSION}

The present study documented changes in microbial communities within the water column as a result of increased sulfide exposure during a sulfide irruption event in the Salton Sea. Based on community structure and composition, samples collected from recently mixed regions of the lake were easily distinguished from those less impacted by sulfide-rich bottom waters. This was surprising since evidence of thermal stratification was absent, indicating that the majority of the lake was well mixed prior to sampling. These sample distinctions appeared to result from differences in abundance of several functionally important microbial lineages. Archaeal diversity was found to be significantly lower than bacterial diversity, and the phylogenetic diversity of both groups consisted of many lineages capable of utilizing reduced sulfur compounds. To better understand the importance of these events on microbial community dynamics, as well as the cycling of sulfur and sulfur-containing compounds in the Salton Sea, studies of the activities of these microbial assemblages are needed.

Acknowledgements. We thank M. A. Tiffany and S. H. Hurlbert for providing physical and chemical data, and assistance with sample collection, $M$. Breitbart for providing DNA extraction procedures, C. N. Desautels and P. M. Morris for assistance with T-RFLP and sequencing, and B. Brinegar of Environmental Recovery Solutions for providing boat logistics. This work was supported by National Science Foundation (NSF) grant MCB-0604191 to D.L.V. and a California NASA Space Grant to B.K.S. Additional support was provided by a Philip and Aida Siff Education Foundation Graduate Fellowship to B.K.S., and a NASA Earth Systems Science Fellowship to K.M.R. Suggestions and comments provided by 2 anonymous reviewers greatly improved the manuscript.

\section{LITERATURE CITED}

Altschul SF, Gish W, Miller W, Myers EW, Lipman DJ (1990) Basic local alignment search tool. J Mol Biol 215:403-410 Ashelford KE, Chuzhanova NA, Fry JC, Jones AJ, Weightman AJ (2006) New screening software shows that most recent large 16S rRNA gene clone libraries contain chimeras. Appl Environ Microbiol 72:5734-5741

> Avaniss-Aghajani E, Jones K, Chapman D, Brunk C (1994) A molecular technique for identification of bacteria using small subunit ribosomal RNA sequences. Biotechniques 17:144-149

Barić A, Grbec B, Kušvpilić G, Marasović I, Ninãvević Ž, Grubelić I (2003) Mass mortality event in a small saline lake (Lake Rogoznica) caused by unusual holomictic conditions. Sci Mar 67:129-141

Barrett EL, Kwan HS (1985) Bacterial reduction of trimethylamine oxide. Annu Rev Microbiol 39:131-149

Brinkhoff T, Muyzer G, Wirsen CO, Kuever J (1999) Thiomicrospira chilensis sp. nov., a mesophilic obligately chemolithoautotrophic sulfur-oxidizing bacterium isolated from a Thioploca mat. Int J Syst Bacteriol 49:875-879

Bryant DA, Frigaard NU (2006) Prokaryotic photosynthesis and phototrophy illuminated. Trends Microbiol 14: 488-496

Carmichael WW, Li R (2006) Cyanobacteria toxins in the Salton Sea. Saline Syst 2:5

Ciglenečki I, Carić M, Kršinić F, Viliãić D, Ćosović B (2005) The extinction by sulfide-turnover and recovery of a naturally eutrophic, meromictic seawater lake. J Mar Syst 56: 29-44

Clarke KR (1993) Non-parametric multivariate analyses of changes in community structure. Aust J Ecol 18:117-143

Clarke KR, Warwick RM (2001) Change in marine communities: an approach to statistical analysis and interpretation, 2nd edn. PRIMER-E, Plymouth

Cole JR, Wang Q, Cardenas E, Fish J and others (2009) The ribosomal database project: improved alignments and new tools for rRNA analysis. Nucleic Acids Res 37: D141-D145

> Detwiler PM, Coe MF, Dexter DM (2002) The benthic invertebrates of the Salton Sea: distribution and seasonal dynamics. Hydrobiologia 473:139-160

> Dillon JG, McMath LM, Trout AL (2009) Seasonal changes in bacterial diversity in the Salton Sea. Hydrobiologia 632: 49-64

Effler SW, Hassett JP, Auer MT, Johnson N (1988) Depletion of epilimnetic oxygen and accumulation of hydrogen sulfide in the hypolimnion of Onondaga Lake, NY, USA. Water Air Soil Pollut 39:59-74

Fallesen G, Andersen F, Larsen B (2000) Life, death and revival of the hypertrophic Mariager Fjord, Denmark. J Mar Syst 25:313-321

Fuller NJ, Marie D, Partensky F, Vaulot D, Post AF, Scanlan DJ (2003) Clade-specific 16S ribosomal DNA oligonucleotides reveal the predominance of a single marine Synechococcus clade throughout a stratified water column in the Red Sea. Appl Environ Microbiol 69:2430-2443

Hiraishi A, Ueda Y (1994) Intrageneric structure of the genus Rhodobacter: transfer of Rhodobacter sulfidophilus and related marine species to the genus Rhodovulum gen. nov. Int J Syst Bacteriol 44:15-23

Huber T, Faulkner G, Hugenholtz P (2004) Bellerophon: a program to detect chimeric sequences in multiple sequence alignments. Bioinformatics 20:2317-2319

Junier P, Junier T, Witzel KP (2008) TRiFLe, a program for in silico terminal restriction fragment length polymorphism analysis with user-defined sequence sets. Appl Environ Microbiol 74:6452-6456

Kiene RP, Oremland RS, Catena A, Miller LG, Capone DG (1986) Metabolism of reduced methylated sulfur compounds in anaerobic sediments and by a pure culture of an estuarine methanogen. Appl Environ Microbiol 52: 1037-1045

> Kiene RP, Linn LJ, Bruton JA (2000) New and important roles for DMSP in marine microbial communities. J Sea Res 43: 209-224

Lane DJ (1991) 16S/23S rRNA sequencing. In: Stackebrandt E, Goodfellow M (eds) Nucleic acid techniques in bacterial systematics. John Wiley \& Sons, Chichester, p 115-175

Lane DJ, Pace B, Olsen GJ, Stahl DA, Sogin ML, Pace NR (1985) Rapid determination of 16S ribosomal RNA sequences for phylogenetic analyses. Proc Natl Acad Sci USA 82:6955-6959

Lavik G, Stuhrmann T, Bruchert V, Van der Plas A and others (2009) Detoxification of sulphidic African shelf waters by blooming chemolithotrophs. Nature 457:581-584

Lee K, Choo YJ, Giovannoni SJ, Cho JC (2007) Maritimibacter alkaliphilus gen. nov., sp. nov., a genomesequenced marine bacterium of the Roseobacter clade in 
the order Rhodobacterales. Int J Syst Evol Microbiol 57: 1653-1658

Luo YH, Mitsui A (1996) Sulfide as electron source for $\mathrm{H}_{2}$ photoproduction in the cyanobacterium Synechococcus sp., strain Miami BG 043511, under stress conditions. J Photochem Photobiol B 35:203-207

Luther GWI, Ma S, Trouwborst R, Glazer B, Blickley M, Scarborough RW, Mensinger MG (2004) The roles of anoxia, $\mathrm{H}_{2} \mathrm{~S}$, and storm events in fish kills of dead-end canals of Delaware inland bays. Estuaries 27:551-560

Malakoff D (1998) Death by suffocation in the Gulf of Mexico. Science 281:190-192

McCune B, Grace JB, Urban DL (2002) Analysis of ecological communities. MJM Software Design, Glendon Beach, OR

Miller SR, Bebout BM (2004) Variation in sulfide tolerance of photosystem II in phylogenetically diverse cyanobacteria from sulfidic habitats. Appl Environ Microbiol 70:736-744

Millero FJ, Hubinger S, Fernandez M, Garnett S (1987) Oxidation of $\mathrm{H}_{2} \mathrm{~S}$ in seawater as a function of temperature, $\mathrm{pH}$, and ionic strength. Environ Sci Technol 21:439-443

> Mochimaru H, Uchiyama H, Yoshioka H, Imachi H and others (2007) Methanogen diversity in deep subsurface gas-associated water at the Minami-Kanto gas field in Japan. Geomicrobiol J 24:93-100

Naqvi SWA, Jayakumar DA, Narvekar PV, Naik H and others (2000) Increased marine production of $\mathrm{N}_{2} \mathrm{O}$ due to intensifying anoxia on the Indian continental shelf. Nature 408: 346-349

- Niizeki N, Daikoku T, Hirata T, El-Shourbagy I, Song X, Sakaguchi M (2003) Mechanism of biosynthesis of trimethylamine oxide in tilapia reared under seawater conditions. Fish Sci 69:74-87

Oremland RS, Marsh L, Desmarais DJ (1982) Methanogenesis in Big Soda Lake, Nevada: an alkaline, moderately hypersaline desert lake. Appl Environ Microbiol 43:462-468

Oren A (1990) Formation and breakdown of glycine betaine and trimethylamine in hypersaline environments. Antonie van Leeuwenhoek 58:291-298 doi:10.1007/BF00399342

Orphan VJ, Jahnke LL, Embaye T, Turk KA, Pernthaler A, Summons RE, Des Marais DJ (2008) Characterization and spatial distribution of methanogens and methanogenic biosignatures in hypersaline microbial mats of Baja California. Geobiology 6:376-393

Page RDM (1996) Tree view: an application to display phylogenetic trees on personal computers. Bioinformatics 12: 357-358

Reese BK, Anderson MA (2009) Dimethyl sulfide production in a saline eutrophic lake, Salton Sea, California. Limnol Oceanogr 54:250-261

Reifel KM, McCoy MP, Rocke TE, Tiffany MA, Hurlbert SH, Faulkner DJ (2002) Possible importance of algal toxins in the Salton Sea, California. Hydrobiologia 473:275-292

Riedel R, Caskey L, Costa-Pierce BA (2002) Fish biology and fisheries ecology of the Salton Sea, California. Hydrobiologia 473:229-244

Schloss PD, Handelsman J (2005) Introducing DOTUR, a computer program for defining operational taxonomic units and estimating species richness. Appl Environ Microbiol 71:1501-1506

Seliger HH, Boggs JA, Biggley WH (1985) Catastrophic anoxia in the Chesapeake Bay in 1984. Science 228:70-73

Serrano W, Amann R, Fischer U (2009) A new moderately thermophilic and high sulfide tolerant biotype of Marichromatium gracile, isolated from tidal sediments of the German Wadden Sea: Marichromatium gracile biotype thermosulfidiphilum. Syst Appl Microbiol 32:1-7

Sørensen KB, Canfield DE, Oren A (2004a) Salinity responses of benthic microbial communities in a solar saltern (Eilat, Israel). Appl Environ Microbiol 70:1608-1616

> Sørensen KB, Lauer A, Teske A (2004b) Archaeal phylotypes in a metal-rich and low-activity deep subsurface sediment of the Peru Basin, ODP Leg 201, Site 1231. Geobiology 2: 151-161

Swan BK, Reifel KM, Tiffany MA, Watts JM, Hurlbert SH (2007) Spatial and temporal patterns of transparency and light attenuation in the Salton Sea, California, 1997-1999. Lake Reservior Manag 23:653-662

Swan BK, Ehrhardt CJ, Reifel KM, Moreno LI, Valentine DL (2010) Archaeal and bacterial communities respond differently to environmental gradients in anoxic sediments of a California hypersaline lake, the Salton Sea. Appl Environ Microbiol 76:757-768

Swofford DL (2003) PAUP*. Phylogenetic analysis using parsimony ( ${ }^{*}$ and other methods), Version 4.0. Sinauer Associates, Sunderland, MA

Takeda S, Nimura Y, Hirano R (1991) Optical, biological, and chemical properties of Aoshio, hypoxic milky blue-green water, observed at the head of Tokyo Bay. J Oceanogr Soc Jpn 47:126-137

Thompson JD, Gibson TJ, Plewniak F, Jeanmougin F, Higgins DG (1997) The CLUSTAL_X windows interface: flexible strategies for multiple sequence alignment aided by quality analysis tools. Nucleic Acids Res 25:4876-4882

Tiffany MA, Swan BK, Watts JM, Hurlbert SH (2002) Metazooplankton dynamics in the Salton Sea, California, 1997-1999. Hydrobiologia 473:103-120

Tiffany MA, González MR, Swan BK, Reifel KM, Watts JM, Hurlbert SH (2007a) Phytoplankton dynamics in the Salton Sea, California, 1997-1999. Lake Reservior Manag 23:582-605

Tiffany MA, Swan BK, Gebler GF, Cole JC and others (2007b) Ciliate plankton dynamics and survey of ciliate diversity in the Salton Sea, California, 1997-1999. Lake Reservior Manag 23:606-619

> Tiffany MA, Ustin SL, Hurlbert SH (2007c) Sulfide irruptions and gypsum blooms in the Salton Sea as detected by satellite imagery, 1979-2006. Lake Reservior Manage 23:637-652

Turner ER, Rabalais NN (1994) Coastal eutrophication near the Mississippi river delta. Nature 368:619-621

Vairavamurthy AM, Andreae MO, Iverson RL (1985) Biosynthesis of dimethylsulfide and dimethylpropiothetin by Hymenomonas carterae in relation to sulfur source and salinity variations. Limnol Oceanogr 30:59-70

Watts JM, Swan BK, Tiffany MA, Hurlbert SH (2001) Thermal, mixing, and oxygen regimes of the Salton Sea, California, 1997-1999. Hydrobiologia 466:159-176

Weeks SJ, Currie B, Bakun A (2002) Satellite imaging: massive emissions of toxic gas in the Atlantic. Nature 415: 493-494

Weeks SJ, Currie B, Bakun A, Peard KR (2004) Hydrogen sulphide eruptions in the Atlantic Ocean off southern Africa: implications of a new view based on SeaWiFS satellite imagery. Deep-Sea Res I 51:153-172

Wood AM, Miller SR, Li WKW, Castenholz RW (2002) Preliminary studies of cyanobacteria, picoplankton, and virioplankton in the Salton Sea with special attention to phylogenetic diversity among eight strains of filamentous cyanobacteria. Hydrobiologia 473:77-92 